Research Article

\title{
Journey from basic to advanced laparoscopic surgery: our experience at UP Rural Institute of Medical Sciences and Research, Saifai, Uttar Pradesh, India
}

\author{
Vikas Singh*, Poonam Gupta, Sunil K. Singh, Rudramani, Shesh Kumar, \\ Ramit Chandra Singh, Vijay Kumar
}

Department of Surgery, UP Rural Institute of Medical Sciences and Research, Saifai, Etawah (UP)- 206301, India

Received: 29 March 2016

Accepted: 04 April 2016

\section{*Correspondence:}

Dr. Vikas Singh,

E-mail: drvikas_singh@yahoo.com

Copyright: $($ ) the author(s), publisher and licensee Medip Academy. This is an open-access article distributed under the terms of the Creative Commons Attribution Non-Commercial License, which permits unrestricted non-commercial use, distribution, and reproduction in any medium, provided the original work is properly cited.

\begin{abstract}
Background: Laparoscopic surgery has completed twenty-five years since its inception. Almost all the surgical procedures are being done by laparoscopy. Primary goal of a laparoscopic procedure is to achieve good cosmetic outcome, reduced post-operative pain, early recovery and reduced hospital admission. The main objective of this study is to see the feasibility and benefit of performing advance laparoscopic surgery in a new rural institute where basic laparoscopic surgery is done and to share our experience.

Methods: A retrospective study of case sheets and discharge summary from $1^{\text {st }}$ Jan 2012 till $1^{\text {st }}$ December 2015 was done. Altogether 400 patients underwent different advanced laparoscopic procedure. Cases done for the first time in the institute and those done by a single unit were only included. Technical feasibility, successful completion, operative time, duration of hospital stays and patients' satisfaction regarding minimal scars were assessed.

Results: All patients were aged between 13-75 years. Out of 400 patients, 270 were females and 130 were males. All procedures were technically feasible with basic laparoscopic instruments. Early ambulation and enteral feed was done within 24 hours in all and within 48 hours in patients who had bowel anastomosis. Postoperative hospital stay was 2-8 days. All appreciated cosmetic scar.

Conclusions: Advanced laparoscopy is feasible, safe and effective in the hand of surgeons performing basic laparoscopic surgeries. Evaluation and monitoring in a systematic scientific manner will benefit the surgeon with a satisfactory learning curve that will ensure that patient welfare is not compromised. Persistence and perseverance is the key. Last but not the least; develop a team for better results.
\end{abstract}

Keywords: Advanced laparoscopic surgery

\section{INTRODUCTION}

With advances in minimal invasive surgery and increase in confidence level of laparoscopic surgeon, many advance laparoscopic procedure are feasible and are being performed worldwide. ${ }^{1}$ However, still laparoscopic surgeons are not willing to indulge in advance laparoscopic procedures because of many factors. Hence, this study helps to know feasibility, advantage and disadvantage of advance laparoscopic surgery in a new rural institute.

\section{METHODS}

A retrospective analysis of all the cases that underwent different advance laparoscopic procedures for various disease conditions were included from $1^{\text {st }}$ Jan 2012 till Dec 2015. Case sheets and discharge summary of each were analyzed.

All the patients admitted under a single unit through outdoor in the Department of Surgery over the past three years in UP Rural Institute of Medical Sciences and Research, Saifai, Etawah for elective surgeries. 
A total number of 400 patients were subjected to various advanced laparoscopic procedures under general anaesthesia after proper convincing and informed consent. All patients were aged between 13-75 years. Out of all patients, 270 were females and 130 were males.

The instrumentation used was the laparoscopy set available in our operation theatre. Stryker HD (1288) was used for most of the procedures.

Veress needle for initial creation of pneumoperitoneum was used. Telescopes $-10 \mathrm{~mm}$ and $5 \mathrm{~mm}$ diameter, both $0^{\circ}$ and $30^{\circ}$ as per need.

The energy sources used were electrocautery-monopolar, ultrasonic harmonic scalpel (Ethicon), ligasure and enseal. All the advanced laparoscopic procedure done first time in this institute and done by the author only was included.

First camera port was placed in umbilicus followed by working ports to suit the ergonomics for that particular procedure except for retroperitoneal pyelolithotomy. Additional ports were placed as per requirement.

Objective was to assess the following parameters on the procedures performed laparoscopically,

- Feasibility

- Successful completion

- Operative time

- Intra-operative difficulty

- Conversions

- Duration of hospital stay

- Complications

- To motivate all young surgeons in the field of laparoscopic surgery to enhance their skills and venture into the world of advanced laparoscopic surgery.

\section{RESULTS}

All patients were aged between 13-75 years. Out of 400 patients, 270 were females and 130 were males. All procedures were technically feasible with basic laparoscopic instruments. Early ambulation and enteral feed was done within 24 hours in all and within 48 hours in patients who had bowel anastomosis. Postoperative hospital stay was 2-8 days. All appreciated cosmetic scar.

\section{DISCUSSION}

Laparoscopic surgery has proven the improved health related outcomes. Around 20 years after first laparoscopic cholecystectomy, other advanced laparoscopic surgery was initiated. Unlike laparoscopic cholecystectomy none has become the gold standard treatment but has emerged as an alternate treatment modality with better cosmesis, early recovery and safe.
Table 1A: Showing the successful laparoscopic procedures with operative time and hospital stay.

\begin{tabular}{|llll|}
\hline Procedure & $\begin{array}{l}\text { No. of } \\
\text { patients }\end{array}$ & $\begin{array}{l}\text { Operative } \\
\text { time } \\
\text { (mean in } \\
\text { min) }\end{array}$ & $\begin{array}{l}\text { Hospital } \\
\text { stay } \\
\text { (days) }\end{array}$ \\
\hline $\begin{array}{l}\text { SILC (single } \\
\text { incision lap } \\
\text { cholecystectomy) }\end{array}$ & 252 & 45 & 1.5 \\
\hline $\begin{array}{l}\text { SILS appendectomy } \\
\text { Interval) }\end{array}$ & 7 & 40 & 2 \\
\hline $\begin{array}{l}\text { Ventral hernia } \\
\text { (Incisional) }\end{array}$ & 17 & 65 & 5 \\
\hline TEP hernia repair & 27 & 55 & 2 \\
\hline SILS TAPP & 4 & 65 & 2 \\
\hline Nephrectomy & 7 & 90 & 5 \\
\hline $\begin{array}{l}\text { Right } \\
\text { hemicolectomy }\end{array}$ & 2 & 120 & 7 \\
\hline Rectopexy (mesh) & 7 & 90 & 5 \\
\hline $\begin{array}{l}\text { Single incision } \\
\text { CBD exploration }\end{array}$ & 2 & 120 & 5 \\
\hline $\begin{array}{l}\text { Low anterior } \\
\text { resection (assisted) }\end{array}$ & 1 & 120 & 7 \\
\hline $\begin{array}{l}\text { Retroperitoneal } \\
\text { pyelolithotomy }\end{array}$ & 27 & 100 & 5 \\
\hline $\begin{array}{l}\text { Lap CBD } \\
\text { exploration }\end{array}$ & 14 & 110 & 5 \\
\hline $\begin{array}{l}\text { Lap removal of } \\
\text { foreign body } \\
\text { (gossypiboma) }\end{array}$ & 1 & 110 & 5 \\
\hline $\begin{array}{l}\text { Lap } \\
\text { pyelolithotomy in } \\
\text { ectopic pelvic } \\
\text { kidney }\end{array}$ & 1 & 70 & 5 \\
\hline Lap VVF repair & 1 & 130 & \\
\hline
\end{tabular}

For performing Single Incision laparoscopic cholecystectomy (SILC), the operative approach was adapted from initial reports describing direct exposure of the peritoneal cavity by a single vertical incision within the umbilicus and sutures to retract the gallbladder. ${ }^{2,3}$

We used only two ports, a $5 \mathrm{~mm}$ trocar on the left side of the umbilicus for $5 \mathrm{~mm} 30^{\circ}$ scope and $10 \mathrm{~mm}$ port on the right side for working instruments with a fascial bridge in between them. A standard-length, $30^{\circ}, 5 \mathrm{~mm}$ laparoscope was used. This was coupled with a high-definition camera and video tower (Stryker 1288). The surgeon held the camera through the inferior umbilical port and the operative instruments via the superior port.

Of the 252 patients operated, 248 (210 women and 38 men) underwent successful SILC. The remaining four patients needed a rescue port in the epigastric region to complete the procedure. In both cases, the conversion occurred because of poor visualization of Calot's triangle. For the SILC cases, the operative times from the initial incision to closure of the wound ranged from 45 to 105 
min. The ages of the patients ranged from 13 to 70 years. Their weights ranged from 30 to $96 \mathrm{~kg}$. All the patients were discharged home the next day then followed up within 2 weeks after discharge. Employed patients returned to work within 2-7 days.

Table 1B: Showing the successful laparoscopic procedures with operative time and hospital stay.

\begin{tabular}{|c|c|c|c|}
\hline Procedure & $\begin{array}{l}\text { No. of } \\
\text { patients }\end{array}$ & $\begin{array}{l}\text { Operative } \\
\text { time } \\
\text { (mean in } \\
\text { min) }\end{array}$ & $\begin{array}{l}\text { Hospital } \\
\text { stay } \\
\text { (days) }\end{array}$ \\
\hline $\begin{array}{l}\text { Lap excision of } \\
\text { Meckel's } \\
\text { diverticulum }\end{array}$ & 1 & 125 & 5 \\
\hline $\begin{array}{l}\text { Lap partial } \\
\text { gastrectomy and } \\
\text { GJ }\end{array}$ & 1 & 130 & 7 \\
\hline $\begin{array}{l}\text { Renal cyst } \\
\text { deroofing }\end{array}$ & 2 & 90 & 3 \\
\hline Splenectomy & 1 & 100 & 5 \\
\hline $\begin{array}{l}\text { Lap jejunal GIST } \\
\text { Excision }\end{array}$ & 1 & 140 & 7 \\
\hline $\begin{array}{l}\text { Lap retroperitoneal } \\
\text { pyeloplasty }\end{array}$ & 2 & 125 & 5 \\
\hline Lap fundoplication & 3 & 130 & 5 \\
\hline $\begin{array}{l}\text { Lap duodenal } \\
\text { perforation repair }\end{array}$ & 1 & 100 & 5 \\
\hline $\begin{array}{l}\text { Lap } \\
\text { cystogastrostomy } \\
\text { for } \\
\text { pseudopancreatic } \\
\text { cyst }\end{array}$ & 1 & 110 & 5 \\
\hline $\begin{array}{l}\text { Concomitant lap } \\
\text { chole, B/L ovarian } \\
\text { cystectomy and } \\
\text { renal cyst } \\
\text { deroofing }\end{array}$ & 1 & 130 & 6 \\
\hline Lap TAPP & 15 & 130 & 3 \\
\hline $\begin{array}{l}\text { Concomitant lap } \\
\text { chole and lap } \\
\text { pyelolithotomy }\end{array}$ & 1 & 130 & 3 \\
\hline
\end{tabular}

Colorectal malignancy managed by laparoscopic procedure has been a subject of intense investigation. Recent date meta-analysis comprising five randomized controlled trials confirmed its acceptable oncological outcome as primary end point and immediate postoperative outcome as secondary end point. ${ }^{4,5}$ To satisfy the oncological principle, 12 nodes are to be harvested from the resected specimen where as in our case 14 nodes were identified in histopathological examination.

There is ongoing debate regarding the management of choledocholithiasis. The advantage of laparoscopic common bile duct (CBD) exploration over ERCP followed by laparoscopic cholecystectomy is that it is a one staged procedure. Laparoscopic CBD exploration is limited by its long learning curve and it is technically demanding. ${ }^{6}$ Transcystic CBD exploration has high success rate and low morbidity. ${ }^{7}$ But its application is in wide cystic duct to negotiate choledochoscope and small stones in the CBD. However, with use of semi rigid ureteroscope as a choledochoscope or a flexible choledochoscope in transcystic or trans-common bile duct have two advantages; one use of irrigation port and another use of working port for retrieval of stone with use of forceps or dormia. Flexible choledochoscope for CBD stone removal and to check the stone clearance.

Laparoscopic splenectomy has been an obvious alternative to open surgery for non-enlarged spleen. For massive splenomegaly, it is feasible to mobilize and dissect inside the abdomen. But its manipulation and retrieval is cumbersome. ${ }^{8}$ High conversion rate and morbidity are reported in literatures. ${ }^{9}$ In my case there was conversion to open due to bleeding from hilum.

Laparoscopic nephrectomy has been one of the modalities for treatment non-functioning kidney. ${ }^{10}$ In one patient transperitoneal approach was done for huge hydronephrotic nonfunctioning kidney with use of basic laparoscopic instruments.

There were 27 cases of laparoscopic retroperitoneal pyelolithotomy. The first port was inserted through a 10 $\mathrm{mm}$ incision made just below the tip of the twelfth rib. The muscles were divided under vision; the dorsolumbar fascia was incised and the retroperitoneal space was entered. Indigenous gloved finger over a $5 \mathrm{~mm}$ port was inserted and inflated with saline (approximately 150-200 $\mathrm{ml}$ ) for retroperitoneal space creation. The balloon was kept inflated for 3-5 minutes to achieve hemostasis. The second $10 \mathrm{~mm}$ port was placed in the line of the first port, just above the iliac crest. The third $5 \mathrm{~mm}$ port was placed anteriorly, midway between the first two ports, in such a manner that the three ports formed an equilateral triangle. The fourth port was placed as per the need for insertion of DJ stent intraoperatively. We preferred to approach the pelvis of the kidney directly, however in cases where the pelvis was either not easily accessible or there was an aberrant vessel, the upper end of the ureter was exposed and it was traced up to the pelvis. The pelvis was dissected and a pyelotomy incision was made with a hook dissector using monopolar cautery. The Gil-Vernet's plane was dissected wherever necessary, to carry out extended pyelolithotomy.

Dissection, electrocautery and clipping were done with instruments used in basic laparoscopy. Intracorporal knot tying was done where blood vessels were big for clipping. Suturing, if required, was done intracorporeal and bowel anastomosis was completed using Endo GIA staplers. We were lucky to have various energy sources at our disposal like electrocautery-monopolar, ultrasonic harmonic scalpel (Ethicon), ligasure and enseal. 


\section{CONCLUSION}

Laparoscopic surgery is here to stay and success in it is determined by how quickly and effectively we learn. Certain measures may be taken to lessen some of the adverse effects of the learning curve and others to help laparoscopic surgeons ease into the specialist. The message for individual surgeons is to identify their deficiencies, and chart a way forward for their personal graph of progress. Evaluation and monitoring in a systematic scientific manner will benefit the surgeon with a satisfactory learning curve that will ensure that patient welfare is not compromised. Persistence and perseverance is the key. Develop a team for better results. Proper training/courses for advanced laparoscopic procedures should be done. It is important to train the postgraduates and residents so that future laparoscopic surgery is widely available for the common population with a lesser complication and a higher safety margin.

Funding: No funding sources

Conflict of interest: None declared

Ethical approval: The study was approved by the institutional ethics committee

\section{REFERENCES}

1. Thomas RG. US experience with laparoscopic cholecystectomy. Am J Surg. 1993;165:450-3.

2. Cuesta MA, Berends F, Veenhof AA. The invisible cholecystectomy: a transumbilical laparoscopic operation without a scar. Surg Endosc. 2008;22:1211-3.

3. Merchant AM, Cook MW, White BC, Davis SS, Sweeney JF, Lin E. Transumbilical gelport access technique for performing single-incision laparoscopic surgery (SILS). Gastrointest Surg. 2009;13:159-62.

4. Kuhry E, Schwenk W, Gaupset R, Romild U, Bonjer J. Long-term outcome of laparoscopic surgery for colorectal cancer: a cochrane systematic review of randomised controlled trials. Cancer Treat Rev. 2008;34:498-504.

5. Jayne DG, Guillou PJ, Thorpe H, Quirke P, Copeland J, Smith AM et al. Randomized trial of laparoscopic-assisted resection of colorectal carcinoma: 3-year results of the UK MRC CLASICC Trial Group. J Clin Oncol. 2007;25(21):3061-8.

6. Handoff JM, Hall JC. Acquiring surgical skills. Br J Surg. 2000;87(1):28-37.

7. Carroll BJ, Phillips EH, Rosenthal R. Update on transcystic exploration of the bile duct. Surg laparoscope Endos. 1996;6:453-8.

8. Taragona EM, Balgue C, Trias M. Laparoscopic splenectomy for splenomegaly. In: Kathkhouda N, editor. Surgical disease of the spleen. Problems in general surgery. vol 19. Philadelphia: Lippincott, Williams and Wilkins; 2002:95-101.

9. Kercher KW, Mathews BD, Walsh RM, Sing RF, Backus CL, Heniford BT. Laparoscopic splenectomy for massive splenomegaly. Am J Surg. 2002;183:192-6.

10. Eraky I, EL Kappany H, Ghoneim MA. Laparoscopic nephrectomy: mansoura experience with 106 cases. Br J Urol. 1995;75:271-5.

Cite this article as: Singh V, Gupta P, Singh SK, Rudramani, Kumar S, Singh RC, Kumar V. Journey from basic to advanced laparoscopic surgery: our experience at UP Rural Institute of Medical Sciences and Research, Saifai, Uttar Pradesh, India. Int Surg J 2016;3:501-4. 